\title{
Malformations and Neonatal Problems in Babies of Mothers with Epilepsy: What are the Possible Problems in Women with Epilepsy during Pregnancy?
}

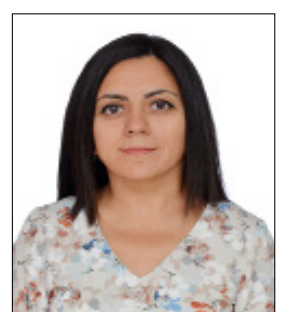

Dr. Selda KESKIN GÜLER

\section{Epilepsi Tanısı Olan Annelerden Doğan Bebeklerde Malformasyonlar} ve Neontalojik Sorunlar: Epilepsi Tanısı Olan Kadınların Gebeliği Hangi Sorunlara Gebe?

\author{
단 Selda KESKIN GÜLER, ${ }^{1}$ ○ Dilek KAHVECIOĞLU² \\ 'Department of Neurology, Ankara Trainig and Research Hospital, Ankara, Turkey \\ 2Department of Neonatology, Ankara Trainig and Research Hospital, Ankara, Turkey
}

\begin{abstract}
Summary
Objectives: This study aims to investigate the effects of epilepsy and its treatment on maternal and fetal outcomes during pregnancy.

Methods: This study was designed as a retrospective observational case-control study. One hundred sixty-nine pregnant women (PW) and their newborns were included. The study group consisted of PW with epilepsy (PWWE)(mean age: 27.6 years; $n=89$ ), and the control group comprised PW without epilepsy (mean age: 27.5 years; $n=80$ ).

Results: In the PWWE, unintended pregnancy was found to be higher $(p<0.001)$. Pregnancy complications and cesarean incidence were higher in the PWWE than in the control group. Time of birth was significantly earlier in the PWWE $(p<0.01)$. No significant difference was found between the groups concerning birth weight, height, sex of infants, and the incidence of birth complications. In the postpartum sixth week visit, all mothers in the control group were nursing their infants, whereas $11.4 \%$ of the PWWE were not nursing their infants $(n=10)(p<0.05)$. During the study, two mothers, and one baby with severe malformation died. The prevalence of major congenital malformations (MCMs) was found as $0 \%$ in the drug-free group, $5.7 \%$ in the mono therapy group, and $8.3 \%$ in the polytherapy group, respectively. Conclusion: Although the majority of the mothers with epilepsy have a healthy pregnancy and healthy baby, we found that the mortality rate and risk of experiencing serious problems in the perinatal and postnatal period were higher compared with the controls. Neonatal disorders and congenital malformations were more common in these infants. It is important that these patients should be followed up closely during the pre-conception, pregnancy, and postpartum periods, and infants should be followed up in tertiary neonatal intensive care units when necessary.
\end{abstract}

Keywords: Antiepileptic drugs; epilepsy; malformation; newborn; pregnancy.

\section{Özet}

Amaç: Epilepsi varlığının ve tedavisinin gebelik boyunca maternal ve fetal sonuçlarının incelenmesi amaçlandı.

Gereç ve Yöntem: Çalışma geriye dönük gözlemsel olgu-kontrol çalışması olarak tasarlandı. Çalışmaya 169 doğum yapmış kadın ve bu kadınlardan doğan bebekleri alındı. Olgu grubu olarak yaş ortalaması 27.6 epilepsi tanısı olan gebe kadın ( $n=89)$ ve kontrol grubu olarak yaş ortalaması 27.5 olan epilepsi olmayan kadın $(\mathrm{n}=80)$ dahil edildi.

Bulgular: Olgu grubunda istenmeyen gebelik daha fazlaydı ( $p<0.001)$. Gebelik komplikasyonları ve sezeryan sıkığı vaka grubunda sağlıklı annelere göre daha fazlaydı. Doğum zamanı olgu grubunda anlamlı derecede daha erkendi $(p<0.01)$. Bebeklerde doğum komplikasyonu sıklığı, cinsiyeti, boy ve kiloları arasında fark saptanmadı. Doğumdan sonraki altıncı hafta kontrolünde kontrol grubundaki annelerin tamamı bebeklerini emzirirken olgu grubunda annelerin \%11.4'ü ( $n=10)$ bebeklerini emzirmiyordu $(p<0.05)$. Calıșma boyunca epilepsi grubunda iki anne ve ciddi malformasoynu olan bir bebek hayatını kaybetti. Doğum salonunda bebeklerde müdahale gerektirecek neonatolojik sorunlar olgu grubunda daha sıktı. Epilepsi tanısı olan kadınlarda majör konjenital malformasoyon (MCM) sıklığı ilaç kullanmayanlarda \%0, monoterapi grubunda $\% 5.7$, politerapi grubunda $\% 8.3$ saptandı.

Sonuç: Her ne kadar annelerin çoğunluğu sağlıklı bir gebelik geçirse ve sağlıklı bir bebeğe sahip olsa da bu çok özel hasta grubunda mortalite oranı, perinatal ve postnatal dönemde ciddi sorunların yaşanma riski epilepsisi olmayan kadınlara göre daha yüksektir. Neonatolojik problemler ve konjenital malformasyonlar bu bebeklerde daha sıktır. Bu hastaların, prekonsepsiyonel dönemi içerecek şekilde gebelik sırasında yakından takip edilmesi ve bebeklerin gerekli durumlarda üçüncü basamak yenidoğan yoğun bakım ünitelerinde takip edilmesi önemlidir.

Anahtar sözcükler: Antiepileptik ilaçlar; epilepsi; malformasyon; yenidoğan; gebelik.

Submitted (Geliş): 20.11.2018

Accepted (Kabul) : 13.03.2019 


\section{Introduction}

One of the most challenging problems in the daily practice of neurologists is deciding whether to use antiepileptic drugs during pregnancy because of the possible negative effects of epilepsy itself on pregnancy and childbirth, as well as the known teratogenic adverse effects of antiepileptic drugs (AEDs). The highest rates of various malformations were reported in polytherapy groups with valproic acid (VPA), and the lowest rates were reported in monotherapy groups with lamotrigine (LTG) and levetiracetam (LEV). ${ }^{[1-4]}$

The incidence of babies with major congenital malformations (MCMs) among women using AEDs is considered to be between $4-8 \% .{ }^{[2,5]}$ However, considering the possible adverse effects of seizure during pregnancy, it is often not possible to interrupt AEDs during pregnancy.

Women with epilepsy (WWE), who are in the group accepted as high-risk pregnancies, may encounter pregnancy complications more frequently and neonatal problems, such as the requirement for resuscitation and admission to neonatal intensive care units, are more likely to be encountered in these infants. ${ }^{[6-8]}$ The mortality rate of pregnant women with epilepsy is $0.1 \%$, which is ten times higher than in pregnant women without epilepsy. ${ }^{[6,7,9]}$

The present study aims to assess the presence of MCMs, neonatal problems, and postpartum problems in children of WWE and to compare the findings with children born to women without health problems.

\section{Materials and Methods}

\section{Case selection and study design}

In this study, women who were followed up in the outpatient epilepsy clinic of Ankara Training and Research Hospital were prospectively examined after pregnancy. The diagnosis of epilepsy was confirmed by a neurologist, according to the International League against Epilepsy criteria. ${ }^{[10]}$ Folic acid treatment was continued in patients who started in the preconception period and in patients who were not taking folic acid and began treatment at the first visit. A total of five follow-ups were arranged for each woman, including each trimester, at birth, and the sixth week postpartum. The babies of age-matched mothers without epilepsy born in the obstetric department of our hospital were included in the control group. The babies in both groups were examined in detail by a neonatologist twice at birth and at the sixth week postpartum.

Women who were diagnosed as having epilepsy during gestation or less than one year before gestation, younger than 16 years, holding a psychiatric diagnosis, using medications other than AEDs, who did not want to participate in this study, newborns with incomplete data, and pregnancies resulted in curettage or abortion were excluded from this study. Volunteered women with no history or diagnosis of epilepsy or any other diseases, older than 16 years of age, with no psychiatric symptoms, and who did not take any medication during pregnancy were accepted as a control group.

Eighty-nine women with epilepsy (mean age: 27.6 years) and 80 women in the control group (mean age: 27.5 years) were included in this study. Participants in the study and the control group were selected among volunteers, and informed consent was obtained from each participant. The institutional review board approved this study (27.06.2018/50-511).

\section{Data capture}

Women in both groups completed a questionnaire regarding their demographic data at the first visit. The frequency and types of seizures and the name and dosage of AEDs used during gestation, gestation complications, screening tests, and ultrasonography results were noted throughout the visits. Timing and type of delivery, presence of complications, and the demographic characteristics of the babies were recorded for both the control and the WWE group. Both groups were followed up postpartum at the sixth week and the mothers were encouraged to breastfeed if they reported about negative attitude during the interview. The babies were also examined six weeks after delivery for the presence of minor or MCMs. MCMs were identified according to the list reported in the EUROCAT records. MCM was defined as "the presence of surgically, medically, functional, or cosmetically significant malformation that would require serious treatment at the birth of within the first six weeks after birth".[2,11]

\section{Statistical analysis}

Statistical analysis was performed using the SPSS package program (version 20.0; SPSS Inc., Chicago, IL, USA). Data were analyzed using frequency distributions for categorical variables and descriptive statistics for continuous variables, 
and the results are given as "mean \pm SD." Malformation ratios were calculated as live birth with malformation + pregnancy loss with malformation/total live birth + pregnancy loss with malformation. Ninety-five percent confidence intervals were measured using conventional methods.

Normal distribution of data was evaluated using the Kolmogorov-Smirnov test. The independent sample t-test was performed for data with normal distribution as a parametric test ( $p>0.05$ ), and the Mann-Whitney $U$ test was performed for data with abnormal distribution as a nonparametric test $(p<0.05)$. The Chi-square test was performed for categorical variables. $P<0.05$ was considered as statistical significance.

\section{Results}

One hundred sixty-nine women (89 patients and 80 controls) with a mean age of 27.55 years and their babies were included in this study. There was no difference between the groups concerning age and educational status ( $p>0.05)$. The demographic data, family history, and backgrounds of the WWE and control groups are given in Table 1.

The frequency of familial epilepsy, febrile convulsions (FC) and congenital malformation were found to be statistically significant in the WWE group $(p<0.05)$. Planned pregnancy was found to be significantly higher in the control group $(n=79)$ than in the WWE group $(n=42)(p<0.001)$. In the WWE group, among 47 women who had their first babies, only 33 women underwent first pregnancy and 14 women had abortion history. No difference was observed between the groups concerning fetal death, neonatal death, or spontaneous abortion ( $p>0.05$ ). Eight WWE were treated for infertility before pregnancy; however, all women in the control group conceived spontaneously.

Table 1. Demographic data of the study and control groups

\begin{tabular}{|c|c|c|c|}
\hline & Women with epilepsy & Control & $\mathrm{p}$ \\
\hline Age (Mean $\pm S D)$ & $27.6 \pm 4.99$ & $27.5 \pm 5.44$ & 0.523 \\
\hline Education (n) & & & 0.145 \\
\hline Illiterate & 6 & 11 & \\
\hline$\leq 8$ years & 50 & 45 & \\
\hline $8-12$ years & 26 & 14 & \\
\hline$\geq 12$ years & 7 & 10 & \\
\hline Education level of the spouse (n) & & & 0.381 \\
\hline Illiterate & 6 & 6 & \\
\hline$\leq 8$ years & 47 & 43 & \\
\hline $8-12$ years & 27 & 17 & \\
\hline$\geq 12$ years & 9 & 14 & \\
\hline Epilepsy in spouse (n) (yes/no) & $3 / 86$ & $1 / 79$ & 0.351 \\
\hline Consanguineous marriage (n) & $7 / 82$ & $9 / 71$ & 0.453 \\
\hline Epilepsy history in family (n) & $32 / 57$ & $0 / 80$ & $<0.001^{*}$ \\
\hline Febrile convulsion history in family (n) & $14 / 75$ & $2 / 78$ & $0.003^{*}$ \\
\hline Congenital malformation history in family (n) & $18 / 71$ & $1 / 79$ & $0.001^{*}$ \\
\hline Planned pregnancy (yes/no) (n) & $42 / 47$ & $79 / 1$ & $<0.001^{*}$ \\
\hline Gravida (n) & & & 0.012 \\
\hline Primigravida & 33 & 16 & \\
\hline Multigravida & 56 & 64 & \\
\hline Parity (n) & & & $<0.001^{*}$ \\
\hline Primiparous & 47 & 17 & \\
\hline Multiparous & 42 & 63 & \\
\hline The history of stillbirth (n) & $4 / 85$ & $1 / 79$ & 0.354 \\
\hline The history of neonatal death (n) & $3 / 86$ & $1 / 79$ & 0.431 \\
\hline The history of spontaneous abortion (n) & $20 / 69$ & $14 / 66$ & 0.593 \\
\hline Infertility treatment $(n)$ & $8 / 81$ & $0 / 80$ & $0.005^{*}$ \\
\hline
\end{tabular}

SD: Standard deviation. 
Table 2. The characteristics of the epilepsy in pregnant women with epilepsy

The onset of epilepsy (age), median (interquartile range)

$16(10.5-19.5)$

Duration of epilepsy (years), median (interquartile range)

$10(7-16.5)$

$40 / 49$

Type of the epilepsy ( $\mathrm{n}$ ) (focal/generalized)

$19 / 3 / 1$

Syndrome (n) (juvenile myoclonic epilepsy/juvenile absence epilepsy/Jeavons syndrome)

37

Epilepsy diagnosis in previous pregnancies (n)

32

antiepileptic drug ( $\mathrm{n})$

Not using

Monotherapy (TPM/OXB/VPA/CBZ/LTG/LEV)

$1 / 4 / 8 / 12 / 19 / 25$

Polytherapy (without VPA, with VPA)

Seizure during pregnancy $(\mathrm{n})$

1

Status epilepticus in pregnancy $(n)$

Seizure during labor $(\mathrm{n})$

9

CBZ: Carbam-azepine; OXB: Oxcarbazepine; LEV: Levetiracetam; VPA: Valproic acid; LTG: Lamotrigine; TPM: Topir-amate.

Table 3. The demographical characteristics of baby and mother

\begin{tabular}{|c|c|c|c|}
\hline & Women with epilepsy & Control & $\mathrm{p}$ \\
\hline Pregnancy complication (no/yes) (n) & $52 / 37$ & $70 / 10$ & $<0.001^{*}$ \\
\hline Urinary tract infection & 10 & 8 & \\
\hline Gestational hypertension & 3 & - & \\
\hline Vaginal bleeding & 7 & - & \\
\hline Hyperemesis & 11 & - & \\
\hline Risk of premature delivery & 4 & - & \\
\hline Preeclampsia & 0 & 1 & \\
\hline Anemia & 11 & - & \\
\hline Gestational diabetes mellitus & 3 & 1 & \\
\hline Edema in lower extremities & 3 & - & \\
\hline Deep vein thrombosis & 1 & - & \\
\hline Gestational age (weeks) & 37.3 & 39 & $0.014^{*}$ \\
\hline Type of birth (n) & & & $0.002^{*}$ \\
\hline Vaginal delivery & 32 & 48 & \\
\hline Cesarean section & 56 & 32 & \\
\hline Delivery complication ( $\mathrm{n}$ ) & & & 0.210 \\
\hline Cephalohematoma & 1 & - & \\
\hline Clavicle fracture & 1 & 2 & \\
\hline Difficult birth & 3 & - & \\
\hline \multicolumn{4}{|l|}{$\operatorname{Sex}(n)$} \\
\hline Female/male & $40 / 48$ & $36 / 44$ & 0.538 \\
\hline Birth weight (g) (mean \pm SD) & $3158( \pm 472)$ & $3182( \pm 414)$ & 0.728 \\
\hline Birth height $(\mathrm{cm})($ mean \pm SD) & $49.07( \pm 2.17)$ & $49.05( \pm 1.71)$ & 0.518 \\
\hline Neonatal problems, $\mathrm{n}(\%)$ & $9(10.3)$ & $4(5)$ & 108 \\
\hline Minor congenital malformation, $\mathrm{n}(\%)$ & $1(1.1)$ & $2(2.5)$ & 0.607 \\
\hline Major congenital malformation, $\mathrm{n}(\%)$ & $5(5.7)$ & 0 & 0.060 \\
\hline Intrauterine death, $\mathrm{n}(\%)$ & $2(2.2)$ & 0 & 0.498 \\
\hline Maternal death, $\mathrm{n}(\%)$ & $2(2.2)$ & 0 & 0.498 \\
\hline Breastfeeding (yes/no) (n) & $77 / 10$ & $80 / 0$ & $0.002^{*}$ \\
\hline
\end{tabular}

The characteristics of the WWE are summarized in Table 2.

The average duration of epilepsy was ten years; and $44.9 \%$ of them had focal-onset epilepsy. During gestation, patients were followed up without medication, on monother- 
Table 4. Characteristics of babies with neonatologic problems

\begin{tabular}{lcccccc}
\hline & $\begin{array}{c}\text { Maternal } \\
\text { age }\end{array}$ & AED & $\begin{array}{c}\text { Gestational } \\
\text { age } \\
\text { (weeks) }\end{array}$ & Sex & $\begin{array}{c}\text { Type } \\
\text { of } \\
\text { delivery }\end{array}$ & $\begin{array}{c}\text { Duration of } \\
\text { hospital stay } \\
\text { (days) }\end{array}$ \\
\hline Apnea & 34 & Control & 37 & Female & CS & 7 \\
& 21 & LTG & 39 & Female & CS & 2 \\
Hypoglycemia & 20 & LTG & 40 & Male & Vaginal delivery & 4 \\
Seizure & 24 & LTG & 38 & Female & CS & 6 \\
Transient tachypnea of newborn & 29 & CBZ & 39 & Male & Vaginal delivery & 10 \\
Meconium aspiration & 26 & CBZ+VPA & 41 & Male & CS & \\
Prematurity & 21 & CBZ+LEV+VPA & 39 & Female & Vaginal delivery & \\
Neonatal pneumonia & 30 & Control & 40 & Male & Vaginal Delivery & 10 \\
& 26 & VPA & 38 & Female & CS & 10 \\
& 31 & LEV & 38 & Male & CS & 7 \\
& 20 & Control & 33 & Male & Vaginal Delivery & 7 \\
\hline
\end{tabular}

CS: Cesarean section; ICU: Intensive care unit.

Table 5. Congenital malformations and characteristics

\begin{tabular}{|c|c|c|c|c|c|c|c|c|}
\hline No & $\begin{array}{c}\text { Congenital } \\
\text { malformation type }\end{array}$ & $\begin{array}{l}\text { Congenital } \\
\text { malformation }\end{array}$ & Sex & $\begin{array}{l}\text { Maternal } \\
\text { age }\end{array}$ & $\begin{array}{l}\text { Delivery } \\
\text { type }\end{array}$ & Mother & AED & $\begin{array}{l}\text { AED dosage during } \\
\text { pregnancy } \mathrm{mg} / \mathrm{d}\end{array}$ \\
\hline 1 & Simian line & Minor & Boy & 21 & $\begin{array}{l}\text { Vaginal } \\
\text { delivery }\end{array}$ & Control & & \\
\hline 2 & Pes equinovarus & Minor & Boy & 34 & $\begin{array}{l}\text { Vaginal } \\
\text { delivery }\end{array}$ & Control & & \\
\hline 3 & Scalp hemangioma & Minor & Boy & 26 & CS & PWWE & LTG & 250 \\
\hline 4 & $\begin{array}{l}\text { Congenital hip } \\
\text { dislocation }\end{array}$ & Major & Boy & 24 & CS & PWWE & LEV & 1000 \\
\hline 5 & Microcephaly & Major & Girl & 26 & CS & PWWE & CBZ & 600 \\
\hline 6 & Meningocele & Major & Boy & 23 & CS & PWWE & OXB & 600 \\
\hline 7 & Diaphragm hernias & Major & Girl & 36 & CS & PWWE & LTG & 100 \\
\hline 8 & Fetal valproat syndrome & Major & Boy & 23 & CS & PWWE & VPA & 1000 \\
\hline
\end{tabular}

AED: Antiepileptic drug; CS: Cesarean section; PWWE: Pregnant women with epilepsy; LTG: Lamotrigine; Levetiracetam; CBZ: Carbamazepine; OXB: Oxcarbazepine; VPA: Valproic acid.

apy and on polytherapy constituted $8.9 \%, 77.5 \%$, and $13.5 \%$ of WWE, respectively. Thirty-two women had at least one seizure during gestation (35.9\%), one woman had 2 status epilepticus, and nine women had seizures during delivery. Five of the women who had seizures at delivery underwent a cesarean section (CS). Pregnancy complications were observed more frequently; the rate of CS was higher in the patient group than the control group (Table 3). WWE and control group gave birth at a mean of 37.3 and 39 weeks, respectively and the difference was statistically significant $(p<0.05)$ (Table 3). No significant difference was determined concerning the frequencies of birth complications, sex dis- tribution, and height and weight of the infants (Table 3). In the postpartum sixth week visit, all mothers in the control group were breastfeeding their infants, whereas $11.4 \%$ of the WWE declined breastfeeding $(n=10)(p<0.05)$.

One WWE died due to acute coronary syndrome at the $22^{\text {nd }}$ gestation week of pregnancy and the fetus accepted as intrauterine exitus. Another fetal intrauterine exitus occurred at the $35^{\text {th }}$ week of pregnancy in the WWE group. And also, a maternal exitus was observed during the third postpartum week, a WWE who had a seizure in the presence of the witnesses and died at home. 
Table 6. The number of AEDs and the rate of MCMs in the WWE group

\begin{tabular}{cccc}
\hline & No medication $(n=8)$ & Monotherapy $(n=69)$ & Polytherapy $(n=12)$ \\
\hline MCM, $n(\%)$ & $0(0)$ & $5(5.7)$ & $1(8.3)$ \\
\hline
\end{tabular}

AEDs: Antiepileptic drugs; MCM: Major congenital malformations; WWE: Women with epilepsy.

Problems observed in infants that needed intervention in the delivery room are shown in Table 4. Four infants had severe apnea, one of which was born from a mother in the control group. The other three infants were born from WWE; all were on lamotrigine (LTG).

Congenital malformations detected in the infants are shown in Table 5. In the control group, two different minor malformations in the form of simian line and pes equinovarus were observed, neither of them required surgical or any other interventions. In the patient group, a minor malformation in the form of a hemangioma at the occipitotemporal region was observed in one infant. All MCMs $(n=5)$ were observed in the patient group. They were congenital hip dislocation, microcephaly, meningocele, diaphragm hernia, and fatal valproate syndrome (FVS). The mother of the baby with FVS had status epilepticus twice during her pregnancy and the baby died of sepsis at the third postpartum month.

There was no MCM detected in the patient group without medication, where it was $5.7 \%$ in monotherapy and $8.3 \%$ in the polytherapy group (Table 6).

\section{Discussion}

The main result of this study is that neonatalproblems were encountered in $10.3 \%$ of the infants born from women in WWE and in 5\% of the control group. Essentially, it was reported that a small-significant association of epilepsy and neonatal adverse outcomes occurred in pregnancy. ${ }^{[7]}$ Similarly, our results indicate that neonatal problems are more common in WWE compared with controls. Apnea was the most frequently observed condition in infants. Three of the four babies with apnea were born from women with epilepsy, and all three patients were on LTG treatment during their pregnancy. In our opinion, LTG associated with sudden unexpected death in epilepsy (SUDEP) in women with epilepsy may trigger apnea in infants due to intrauterine exposure. ${ }^{[12]}$

Results of our study showed that only 33 of the 47 patients with epilepsy who gave birth for the first time, had their first gestation. The difference is due to gestations that resulted in spontaneous abortion and curettage. Moreover, $52 \%$ of pregnancies in WWE were unplanned pregnancies. These women had to experience the possible complications of their pregnancies. Women with epilepsy who plan to have a baby should be advised to consult a physician to take necessary precautions, such as AED regulation and starting folic acid replacement, at least three months before conception.

The rate of infertility treatment for pregnancies was determined to be higher in WWE compared with the control group. Infertility and reproductive disorders were reported to be 2-3 times higher in women with epilepsy. ${ }^{[13]}$ Epileptogenic activity may directly stimulate the hypothalamus and hypophysis. Thus, serum levels of prolactin, acute luteinizing hormone (LH), and follicle-stimulating hormone (FSH) increase. Women with epilepsy have lower LH levels and LH pulse frequency changes compared with healthy women. ${ }^{[13]}$ All these hormonal disorders may trigger anovulation and infertility.

Some $1-2 \%$ of the women with epilepsy are at risk of having tonic-clonic seizures at birth. ${ }^{[14]}$ Ten percent of our patients $(n=9)$ had seizures at birth or during the next 24 hours. CS is preferred over vaginal delivery due to the possibility of these women having seizures during childbirth. In fact, five of nine patients who had a seizure in the birth process gave birth by CS. The rate of CS delivery in women with epilepsy is 2.5 times higher than the normal population. ${ }^{[6]}$ CS was more common in WWE compared with the control group due to the maternal choices and the suggestion of the obstetrician. If there is no obstetric obstacle, preferring CS as the delivery method in women with epilepsy does not diminish the possibility of having a seizure; however, it is recommended in selected cases, such as in patients with resistant epilepsy, seizures triggered by hyperventilation or who had a seizure in the last trimester.

Maternal mortality and morbidity are increased in pregnant women with epilepsy compared with the general population. ${ }^{[6,7,11]}$ It was reported that maternal mortality, pregnancy complications, and neonatal problems increased 10 , 1 , and 1.5 times, respectively. ${ }^{[7,15]}$ In our study, several com- 
plications were observed in $42.5 \%$ and $12.5 \%$ of WWE and control groups, respectively, and the difference was found as statistically significant. Furthermore, two patients (2.2\%) died in the course of this study. The first patient died of acute coronary syndrome at the $22^{\text {nd }}$ week of her pregnancy, and the second patient died after a seizure at the postpartum $3^{\text {rd }}$ week. The second patient also had a history of stent placement due to stenosis of the ascending aorta. Comorbid cardiac diseases were apparent in both patients. The maternal mortality rate in pregnant women with epilepsy was reported as high as $0.1 \%$ in the gestational period [9]. However, a much higher rate of $2.2 \%$ was observed in our study, which may be due to the presence of major cardiac problems. These patients should be monitored closely during pregnancy due to both pregnancy complications and high maternal mortality rates.

AEDs used during pregnancy are associated with structural or cognitive teratogenesis on the fetus..$^{[1,17]}$ Although the mechanism of teratogenicity of AEDs has not been clearly elucidated, it was claimed that decreased intrauterine epoxide hydroxylase activity or oxidative damage derived from prostaglandin $\mathrm{H}$ synthase bioactivation by AEDs might play a role in teratogenicity. ${ }^{[18,19]}$

Fatal valproate syndrome (FVS) was observed in one patient (12.5\%) out of our eight patients on VPA polytherapy, supporting the observation of MCMs being observed at the highest level in polytherapy groups containing VPA. ${ }^{[20,21]}$ The other patients in whom MCMs developed in their child were on LEV, CBZ, OXB, and LTG monotherapy. The rate of MCM development in patients on monotherapy was calculated as $5.7 \%$, which was believed to be relatively safer concerning MCM development. Our data also support previous studies, although our patient number is low. ${ }^{[1-3,5]}$ Furthermore, the rate of congenital malformation within the family was higher in WWE compared with the control group, which increases the possibility of malformations in infants.

Our study results suggest that non-VPA agents are more likely to be preferred for women of reproductive age, among other AEDs. A Dutch study showed that newer AEDs are most often prescribed in children. ${ }^{[22]}$ Similarly, it has been reported that the antiepileptic preference has changed for newer antiepileptics in women of childbearing age. ${ }^{[23]}$ In two previous studies conducted in Turkey in 1992 and 2008, the rates of MCMs in pregnant women with epilepsy were found as $11.5 \%$ and $10 \%$, respectively, whereas it was $5.7 \%$ in our study. ${ }^{[24,25]}$ This may be related to the decreased use of VPA in this group of patients.

In our study, the rate of non-breastfeeding patients in the patient group was found as $11.4 \%$, which was statistically significantly higher than in the control group. Breastfeeding reduces the mother's risk of malignancy and diabetes, as well as many other diseases, including infections, diabetes mellitus, and SUDEP, while strengthening the bond between mother and infant. ${ }^{[26]}$ Higher intelligence quotient (IQ) and language scores were reported in infants of breastfeeding mothers on AEDs compared with those whose mothers did not breastfeed. ${ }^{[27]}$ Women with epilepsy should be encouraged to breastfeed their babies in the postpartum period.

Our hospital is a tertiary institution to which patients are referred in our region. It is a hospital where high-risk pregnancies are referred and followed up, and complicated cases are seen more frequently. Therefore, we may have encountered riskier situations compared with the normal population in both the study and control groups in this study. This can be considered as a limitation concerning the generalizability of our study results. We also think that the low number of patients is another limitation of our work.

In conclusion, although the majority of mothers among this very specific group of patients has healthy pregnancies and healthy babies, the mortality rate and risk of experiencing serious problems in the perinatal and postnatal periods are higher compared with women without epilepsy. Neonatal disorders and congenital malformations are more common in infants from women with epilepsy. It is important that these patients should be trained concerning the pre-conception period and be followed closely during pregnancy and followup in tertiary neonatal intensive care units when necessary.

\section{Ethics Committee Approval}

All procedures performed in this study involving human participants were in accordance with the ethical standards of the institutional and/or national research committee and with the 1964 Helsinki declaration and its later amendments or comparable ethical standards.

\section{Peer-review}

Externally peer-reviewed.

\section{Conflict of interest}

The authors declare that they have no conflict of interest. 


\section{Authorship Contributions}

Concept: S.K.G., D.K.; Design: S.K.G., D.K.; Supervision: S.K.G., D.K.; Materials: S.K.G., D.K.; Data collection \&/or processing: S.K.G., D.K.; Analysis and/or interpretation: S.K.G., D.K.; Literature search: S.K.G.; Writing: S.K.G., D.K.; Critical review: S.K.G., D.K.

\section{References}

1. Hernández-Díaz S, Smith CR, Shen A, Mittendorf R, Hauser WA, Yerby $\mathrm{M}$, et al. Comparative safety of antiepileptic drugs during pregnancy. Neurology 2012;78(21):1692-9. [CrossRef]

2. Morrow J, Russell A, Guthrie E, Parsons L, Robertson I, Waddell $\mathrm{R}$, et al. Malformation risks of antiepileptic drugs in pregnancy: a prospective study from the UK Epilepsy and Pregnancy Register. J Neurol Neurosurg Psychiatry 2006;77(2):193-8. [CrossRef]

3. Tomson T, Battino D, Bonizzoni E, Craig J, Lindhout D, Perucca E, et al. Comparative risk of major congenital malformations with eight different antiepileptic drugs: a prospective cohort study of the EURAP registry. Lancet Neurol 2018;17(6):530-8. [CrossRef]

4. Koc G, Guler SK, Karadas O, Yoldas T, Gokcil Z. Fetal safety of levetiracetam use during pregnancy. Acta Neurol Belg 2018;118(3):503-8. [CrossRef]

5. Schachter SC. Risks associated with epilepsy and pregnancy. UpToDate. Available at: https://www.uptodate.com/contents/ risks-associated-with-epilepsy-and-pregnancy. Accessed August 08, 2018.

6. MacDonald SC, Bateman BT, McElrath TF, Hernández-Díaz S. Mortality and morbidity during delivery hospitalization among pregnant women with epilepsy in the United States. JAMA Neurology 2015;72(9):981-8. [CrossRef]

7. Viale L, Allotey J, Cheong-See F, Arroyo-Manzano D, Mccorry $D$, Bagary $M$, et al. Epilepsy in pregnancy and reproductive outcomes: a systematic review and meta-analysis. Lancet 2015;386(10006):1845-52. [CrossRef]

8. Kahvecioğlu D, Tatar Aksoy H, Keskin Güler S, Yılmaz A, Çalışkan Ş, Alioğlu B. Neonatal Outcomes of Epileptic Mothers' Infants in the Tertiary Level Of Neonatal Intensive Care Unit: Results from Single Center. [Article in Turkish]. İSST Derg 2018;10(2):75-80.

9. Edey S, Moran N, Nashef L. SUDEP and epilepsy-related mortality in pregnancy. Epilepsia 55(7):e72-e4. [CrossRef]

10. Fisher RS, Cross JH, D'Souza C, French JA, Haut SR, Higurashi N, et al. Instruction manual for the ILAE 2017 operational classification of seizure types. Epilepsia 2017;58(4):531-42. [CrossRef]

11. EUROCAT (2005) EUROCAT Guide 1.3 and reference documents, instructions for the registration and surveillance of congenital anomalies. Available at: http://www.eurocat.ulster.ac.uk/pdf/ EUROC AT-Guide-1.3.pdf. Accessed Dec 23, 2017.

12. Aurlien D, Larsen JP, Gjerstad, L, Taubøll E. Increased risk of sudden unexpected death in epilepsy in females using lamotrigine: A nested, case-control study. Epilepsia 2012;53(2):258-66.

13. Singh $P$, Singh $M$, Cugati $G$, Singh AK. Effect of epilepsy on female fertility and reproductive abnormalities. J Hum Reprod Sci 2011;4(2):100-1. [CrossRef]
14. Schachter SC, Lockwood CJ. Management of epilepsy during preconception, pregnancy, and the postpartum period. Available at: https://www.uptodate.com/contents/managementof-epilepsy-and-pregnancy. Accessed August 08, 2018.

15. Harden CL, Hopp J, Ting TY, Pennell PB, French JA, Hauser WA, et al. Practice parameter update: management issues for women with epilepsy--focus on pregnancy (an evidence-based review): obstetrical complications and change in seizure frequency: report of the Quality Standards Subcommittee and Therapeutics and Technology Assessment Subcommittee of the American Academy of Neurology and American Epilepsy Society. Neurology 2009;73(2):126-32. [CrossRef]

16. Meador KJ, Baker GA, Browning N, Cohen MJ, Bromley RL, Clayton-Smith J, et al. Effects of fetal antiepileptic drug exposure: outcomes at age 4.5 years. Neurology 2012;78(16):1207-14.

17. Harden CL, Meador KJ, Pennell PB, Hauser WA, Gronsth GS, French JA, et al. Practice parameter update: management issues for women with epilepsy-focus on pregnancy (an evidence-based review): teratogenesis and perinatal outcomes: report of the Quality Standards Subcommittee and Therapeutics and Technology Assessment Subcommittee of the American Academy of Neurology and American Epilepsy Society. Neurology 2009;73(2):133-41. [CrossRef]

18. Finnell RH, Buehler BA, Kerr BM, Ager PL, Levy RH. Clinical and experimental studies linking oxidative metabolism to phenytoin-induced teratogenesis. Neurology 1992;42:25-31.

19. Parman T, Chen G, Wells PG. Free radical intermediates of phenytoin and related teratogens. Prostaglandin $\mathrm{H}$ synthase-catalyzed bioactivation, electron paramagnetic resonance spectrometry, and photochemical product analysis. J Biol Chem 1998;273(39):25079-88. [CrossRef]

20. Tomson T, Battino D, Bonizzoni E, Craig J, Lindhout D, Perucca E, et al. Dose-dependent teratogenicity of valproate in mono-and polytherapy an observational study. Neurology 85(10):866-72.

21. Vajda FJ, Eadie MJ. Maternal valproate dosage and foetal malformations. Acta Neurol Scand 112(3):137-43. [CrossRef]

22. Weijenberg A, Bos JHJ, Schuiling-Veninga CCM, Brouwer OF, Callenbach PMC. Antiepileptic drug prescription in Dutch children from 2006-2014 using pharmacy-dispensing data. Epilepsy Res 2018;146:21-7. [CrossRef]

23. Vajda FJ, O'Brien T, Lander C, Graham J, Eadie M. The efficacy of the newer antiepileptic drugs in controlling seizures in pregnancy. Epilepsia 2014;55(8):1229-34. [CrossRef]

24. Eşkazan E, Aslan S. Antiepileptic therapy and teratogenicity in Turkey. Int J Clin Pharmacol Ther Toxicol 1992;30(8):261-4.

25. Eroğlu E, Gökçil Z, Bek S, Ulaş UH, Odabaşi Z. Pregnancy and teratogenicity of antiepileptic drugs. Acta Neurol Belg 2008 Jun;108(2):53-7.

26. Gerard EE, Meador KJ. Managing Epilepsy in Women. Continuum (Minneap Minn) 2016;22(1 Epilepsy):204-26. [CrossRef]

27. Meador KJ, Baker GA, Browning N, Cohen MJ, Bromley RL, Clayton-Smith J, et al. Breastfeeding in children of women taking antiepileptic drugs: cognitive outcomes at age 6 years. JAMA Pediatr 2014;168(8):729-36. [CrossRef] 